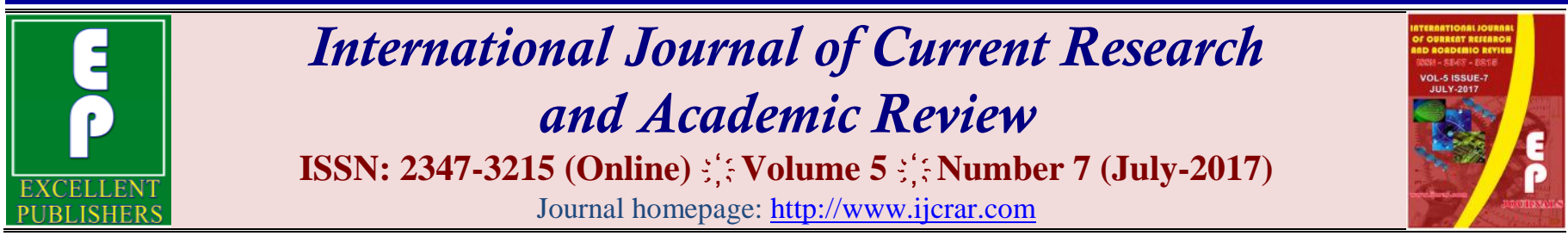

doi: $\underline{\text { https://doi.org/10.20546/ijcrar.2017.507.013 }}$

\title{
Efficacy of the Antiproliferative Effect of L-Asparaginase from Streptomyces enissocaesilis on Different Tumor Cell Lines
}

\author{
B. Sirisha ${ }^{1}$ and R. Haritha ${ }^{2}$ \\ ${ }^{I}$ Department of Biotechnology, College of Science and Technology, Andhra University, Visakhapatnam 530003 , \\ India \\ ${ }^{2}$ Department of Biotechnology, Visakha Government Degree College (Women), Visakhapatnam 530 020, India \\ *Corresponding author
}

\section{Abstract}

The antiproliferative effect of the purified L-Asparaginase enzyme on different tumor human cell lines have been investigated using human leukemic cells. These included MCF 7 (breast cancer cell line), MDA-MB435S (Breast Metastatic cancer), HeLa cell line, Human small cell lung cancer cell line H69PR (ATCC® CRL-11350 ${ }^{\mathrm{TM}}$ ) and COLO 205 (ATCC $®$ CCL-222 $22^{\mathrm{TM}}$ ). The dose- and time-dependent antitumor and cytotoxic effects of L-asparaginase from Streptomyces enissocaesilis have been studied. We investigated the sensitivity of tumor cells towards L-asparaginase, as well the effect of L-asparaginase on cell growth rate, protein and DNA synthesis in the presence of various cytostatics. Cell cycle analysis by flow cytofluorimetry and detection of apoptotic cells before and after treatment with L-asparaginase were studied. Experiments have been conducted to investigate whether administration of Lasparaginase, which results in hydrolysis of extracellular asparagine, arrests asparagine dependent protein synthesis and causes subsequent inhibition of cell growth followed by decreased proliferation of leukemic cells.
\end{abstract}

\section{Article Info}

Accepted: 02 June 2017

Available Online: 20 July 2017

\section{Keywords}

L-asparaginase,

Tumor cells, Cytotoxicity, DNA and protein synthesis, Apoptosis.

\section{Introduction}

L-asparaginase is the first studied enzyme possessing anticancer activity (Pasut et al., 2007). Tumour cells, more specifically lymphatic cells and certain other tumour cells require huge amount of L-asparagine to keep up with their rapid malignant growth but they lack or have a very low level of asparagine synthetase hence do not synthesis L-asparagine denovo. These cells use Lasparagine from the diet (blood stream) to satisfy their large L-asparagine demand (Narta et al., 2007). Lasparaginase catalyzes the hydrolysis of L-asparagine to L-aspartic acid and ammonia thereby selectively kills tumour cells that rely on asparagine supplied by the serum for survival (Uyttebroeck et al., 2008).

Asselin et al., (1989) have studied the cytotoxic action of L-asparaginase both in vitro and in vivo in patients with ALL undergoing treatment with L-asparaginase as a single agent. This study explored the L-asparaginase induced cell cycle arrest in G2/S phase and apoptotic cell death of leukemic cells. It has been reported that there is a requirement of a functional p53 protein for Lasparaginase to induce apoptosis as observed in studies on JURKAT and HL 60 cell lines (Fu et al., 1989, Nandy et al., 1989). Subsequent studies revealed the action of 
L-asparaginase on the various leukemic cells. Human acute lymphoblastic leukemia cell line is markedly inhibited by L-asparaginase, in the G2/S phase (Shimizu et al., 1992). The recent research conventional showed out for the production of L-asparaginase from Penicillium sp. had shown cytotoxic activity (Patro et al., 2012) and the cytotoxic activity of L-asparaginase from the marine actinomycete Streptomyces acrimycini NGP (Selvam and Vishnupriya, 2013).

\section{Materials and Methods}

\section{Cancer Cell Lines}

Human cancer cell lines - MCF-7 Cell line (Breast Cancer), MDA-MB435S Cell line (Breast Metastatic cancer), Human cervical cancer cell line (HeLa), Human small cell lung cancer cell line H69PR (ATCC® CRL$11350^{\mathrm{TM}}$ ) and COLO 205 (ATCC ${ }^{\circledR}$ CCL-222 ${ }^{\mathrm{TM}}$ ) used in this study were procured from National Centre for Cell Science, Pune.

\section{Culturing of cells}

Tumor cells at the logarithmic growth phase with a cell density of $5 \times 10^{8} / \mathrm{L}$ were inoculated into $25 \mathrm{ml}$ culture media containing the purified $L$-asparaginase at a concentration of $200 \mathrm{mg} / \mathrm{L}$. Cells were grown in $5 \%$ $\mathrm{CO}_{2}$ incubator at $37^{\circ} \mathrm{C}$ for $24 \mathrm{~h}$. The morphology of cells was monitored with an inverse microscope. Cells were then isolated by centrifugation at $200 \times g$ for $10 \mathrm{~min}$. After discarding the supernatant, cells were fixed with 4 $\%$ pentadialdehyde for $24 \mathrm{~h}$ followed by a thorough wash with double-distilled water. After dehydration with gradient alcohol washing, cells were embedded with EPON-812 resin. Dissection was accomplished using an LKB-V model microtome. Cell sections were stained with sodium acetate and lead citrate, and subjected to morphology investigation with an $\mathrm{H}-300$ transmission electron microscope.

Cells were cultured in a humid atmosphere $(5 \% \mathrm{CO} 2$, $37^{\circ} \mathrm{C}$ ) using DMEM and RPMI 1640 media, heat inactivated Embryonic Calf Serum (ECS) and Horse Serum (HS) obtained from Gibco (USA). MCF-7 and MDA-MB435S were cultivated in the DMEM medium, HeLa were cultured in the RPMI 1640, Lung cancer cell lines and Colon cancer cell lines were cultivated in the mixture of DMEM and RPMI 1640 (1:1). All media contained 10\% fetal bovine serum (FBS). The media contained $2 \mathrm{mM}$ glutamine, antibiotics penicillin and streptomycin $(10 \mathrm{U} / \mathrm{mL}$ and $10 \mu \mathrm{g} / \mathrm{mL}$, respectively).

\section{Determination of cytotoxic activity of asparaginases}

For detection of cytotoxic antitumor activity of Lasparaginase, the cells were seeded into 96 well plates in $100 \mu \mathrm{l}$ of respective medium containing $10 \%$ FBS at plating density of 10,000 cells/well and incubated at $37^{\circ} \mathrm{C}, 5 \% \mathrm{CO}_{2}, 95 \%$ air and $100 \%$ relative humidity for 24 hours prior to addition of extract. The extract was solubilised in Dimethyl Sulfoxide and diluted in respective serum free medium. After 24 hours, $100 \mathrm{ml}$ of the medium containing the extract at various concentration $(6.25,12.5,25,50,100 \& 200 \mu \mathrm{g} / \mathrm{ml})$ was added and incubated at $37^{\circ} \mathrm{C}, 5 \% \mathrm{CO}_{2}, 95 \%$ air and $100 \%$ relative humidity for 48 hours. Triplicate was maintained and medium containing without extract were served as control. After 48 hours, $15 \mu$ of MTT $(5 \mathrm{mg} / \mathrm{ml})$ in PBS was added to each well and incubated at $37^{\circ} \mathrm{C}$ for 4 hours. The medium with MTT was flicked off and the formed formazan crystals were solubilised in $100 \mu$ of DMSO and then measured the absorbance at $570 \mathrm{~nm}$ using micro plate reader. The $\%$ cell inhibition was determined using following formula.

$$
\% \text { Cell Inhibition }=\frac{\text { Mean Absorbance of Sample }}{\text { Mean Absorbance of Control }} \times 100
$$

\section{Effect of L-asparaginase on protein and cell growth in cancer cells}

The combined effect of asparaginase with cytostatics on protein and cell growth was analyzed using the cytostatic methotrexate $(5 \mu \mathrm{g} / \mathrm{mL})$. Streptomyces enissocaesilis AUBT1404 L-asparaginase concentration was $5.0 \mathrm{IU} / \mathrm{ml}$. The experiments were performed using human leukemia cell lines MCF-7 Cell line (Breast Cancer) and MDAMB435S Cell line (Breast Metastatic cancer). The cell growth and protein synthesis was evaluated by adding 1 $\mu \mathrm{Ci} /$ well of [14C] amino acids and [14C] thymidine, respectively $5 \mathrm{~h}$ before the end of experiments performed in 96 well plates. After this incubation the growth medium was carefully removed and the cell sediment or monolayer was treated overnight at $-10^{\circ} \mathrm{C}$ with $0.1 \mathrm{ml}$ of the ice cold fixing solution ethanol: acetic acid (9: 1) to remove radioactivity of the acid soluble pool (Hashimoto et al., 2009) were then washed with ice cold Hanks solution and after addition of $50 \mu \mathrm{L} 0.3 \mathrm{M} \mathrm{KOH}$ were placed into a thermostat at $37^{\circ} \mathrm{C}$ for $10-12 \mathrm{~h}$. The resultant cell hydrolyzate was neutralized with $1.0 \mathrm{M}$ $\mathrm{HClO}_{4}$ up to $\mathrm{pH} 7.0$ and its radioactivity was counted using a scintillation counter Tri Carb 2800 TR (Perkin Elmer) in Bray liquid. After blank deduction results were calculated as cpm per 106 cells and as \% of control. The 
number of cells was evaluated in the MTT test using data obtained during cell counting in the Goryaev chamber and the extraction value in the MTT test. Statistical treatment of results (including calculation of mean and SD values) and their graphic presentation were performed by the Excel program. Cell cycle analysis by flow cytofluorimetry and detection of apoptotic cells before and after treatment of tumor cells with Lasparaginases were performed as described by Walker et al., (1993). Tumor cells $(0.5 \times 106)$ were cultivated in 25 $\mathrm{cm}^{2}$ flasks containing $5 \mathrm{~mL}$ of the growth medium under standard conditions. After cultivation for $24 \mathrm{~h}$ asparaginase preparation $(5 \mathrm{IU} / \mathrm{mL})$ was added and cultivation continued for $72 \mathrm{~h}$. After this cultivation cell sediment was collected, treated with propidium iodide (Sigma, USA) for analysis in a cytofluorimeter.

\section{Results and Discussion}

The antiproliferative effect of the purified LAsparaginase enzyme on different tumor human cell lines; MCF 7 (breast cancer cell line), MDA-MB435S (Breast Metastatic cancer), HeLa cell line, Human small cell lung cancer cell line H69PR (ATCC® CRL$11350^{\mathrm{TM}}$ ) and COLO 205 (ATCC ${ }^{\circledR}$ CCL-222 ${ }^{\mathrm{TM}}$ ) was assessed by the mitochondrial dependent reduction of yellow MTT (3-(4,5-dimethylthiazol-2- yl)-2, 5-diphenyl tetrazolium bromide) to purple formazan (Mosmann, 1983). The in vitro cytotoxic effect of $S$. enissocaesilis
L-Asparaginase enzyme on the growth of five human tumor cell lines showed that the enzyme had significant inhibitory effects in different cell lines (Tables 1 and 2). However, the highest antitumor activity was recorded towards MCF-7(82.3\%), MDA-MB435S (71.7\%), HeLa and H69PR (ATCC ${ }^{\circledR}$ CRL-11350 ${ }^{\mathrm{TM}}$ ) were less sensitive (\%CI of 64.2 and 60 respectively), while the least activity was obtained towards COLO 205 (52.1\%) when compared with the growth of untreated control cells. The incubation of MCF 7 with gradual doses of $S$. enissocaesilis L-asparaginase lead to a gradual inhibition in the cell growth as depicted by the \% CI values. The inhibitory efficiency to all tumor cells was directly proportional to the dosage applied.

\section{Determination of dose response studies using standard drugs}

Figures 1 and 2 show results of comparative study of the cytotoxic antitumor activities of L-asparaginase and Tamoxifen on MCF 7 cell line and L-asparaginase and Cisplatin on MDA-MB435S, respectively. The results demonstrate that the incubation of MCF 7 (breast cancer cell line) and MDA-MB435S (Breast Metastatic cancer) with increasing amounts of L-asparaginases resulted in a significant dose-dependent decrease in the number of viable (metabolically active) cells as compared with standard drugs.

Table.1 Antitumor activity of purified L-asparaginase on human carcinoma cell lines

\begin{tabular}{|c|c|c|}
\hline CELL LINES & \% CI & \% CS \\
\hline MC-7 & 82.3 & 17.7 \\
\hline MDA-MB435 & 71.7 & 28.3 \\
\hline HeLa & 64.2 & 35.8 \\
\hline H69PR (ATCC $\AA^{\text {CRL-11350 }}{ }^{\text {TM}}$ ) & 60 & 40 \\
\hline COLO 205 (ATCC ${ }^{\text {CCLL-222 }}{ }^{\text {TM }}$ ) & 52.1 & 47.9 \\
\hline
\end{tabular}

Table. 2 The effect of L-asparaginase on the number of tumor cells as shown by results of the MTT test performed at 24,48 , and $72 \mathrm{~h}$ and shown as absorption at $540 \mathrm{~nm}$

\begin{tabular}{|c|c|c|c|}
\hline Leukemia cell line & $\mathbf{2 4} \mathbf{~ h}$ & $\mathbf{4 8 ~ h}$ & $\mathbf{7 2 h}$ \\
\hline MCF-7, Control & 0.230 & 0.595 & 1.110 \\
\hline MCF-7, Experiment & 0.133 & 0.468 & 0.470 \\
\hline MDA-MB435S, Control & 0.160 & 0.196 & 0.312 \\
\hline MDA-MB435S, Experiment & 0.125 & 0.156 & 0.166 \\
\hline
\end{tabular}


Table.3 Cell cycle analysis by flow cytofluorimetry and detection of apoptotic tumor cells after cultivation with Lasparaginases

\begin{tabular}{|c|c|c|}
\hline Groups & MCF-7 & MDA-MB435S \\
\hline Control & & \\
Apoptosis & 21.4 & 24.7 \\
G0/G1 & 40.5 & 37.8 \\
S & 17.2 & 26.1 \\
G2/M & 22.5 & 31.2 \\
\hline S.enissocaesilis L-Asparaginase & & \\
Apoptosis & 90.0 & 87.1 \\
G0/G1 & 49.5 & 40.5 \\
S & 26.7 & 15.2 \\
G2/M & 13.6 & 10.5 \\
\hline
\end{tabular}

Fig.1 Dose-response curve of L-asparaginase on MCF-7 Cell line

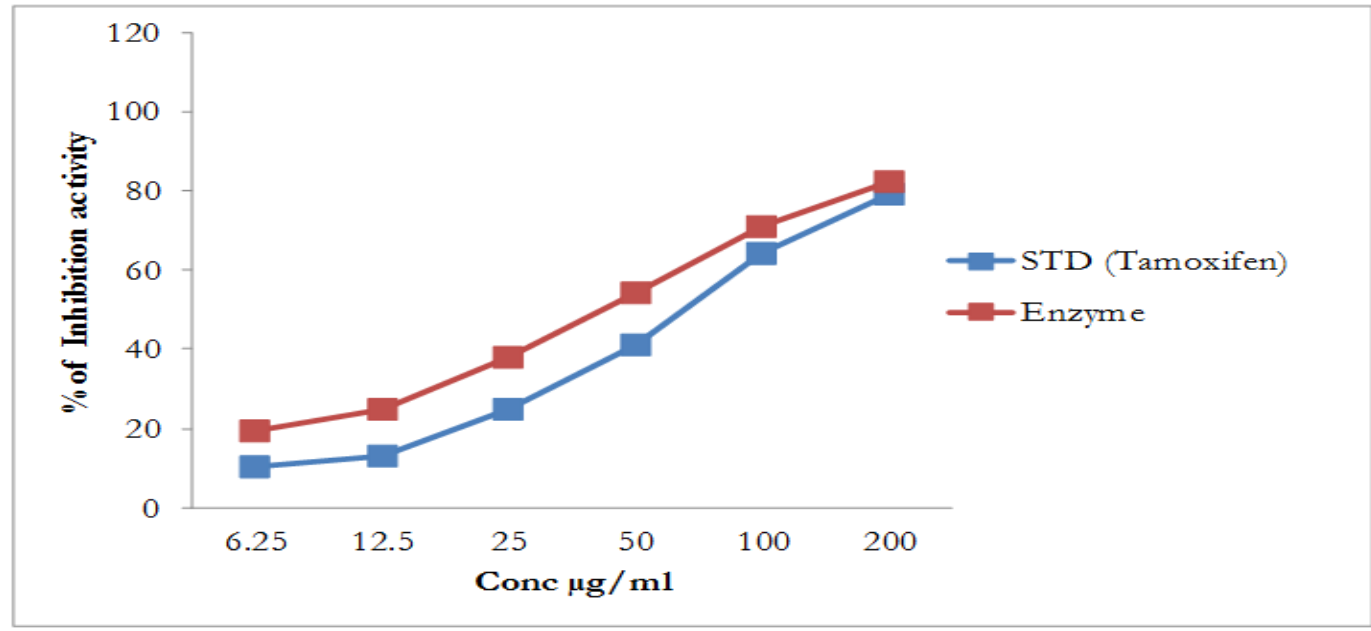

Fig.2 Dose-response curve of L-asparaginase on MDA-MB435S cell line

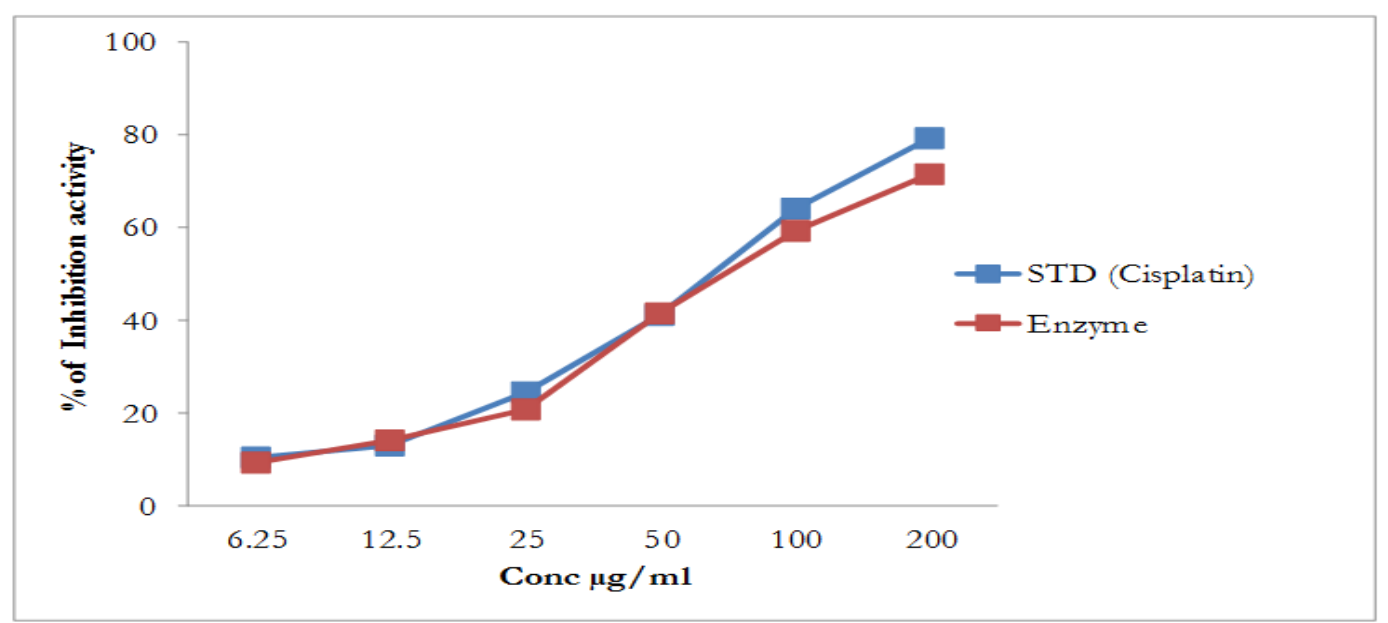


Fig.3 Effect of L-asparaginase on the morphology of the MCF-7cells

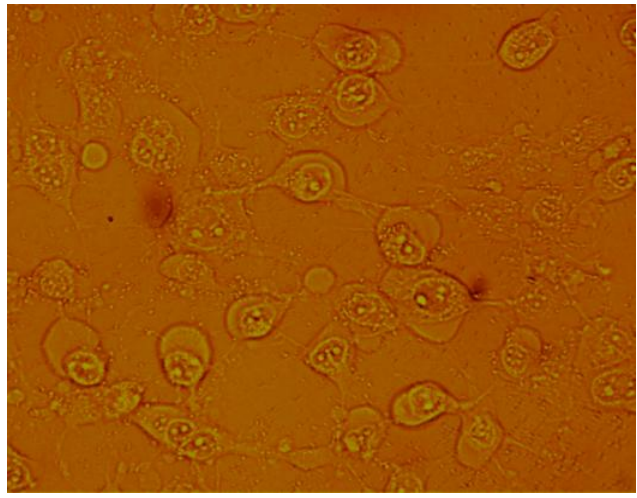

MCF-7 before treatment with L-asparaginase enzyme

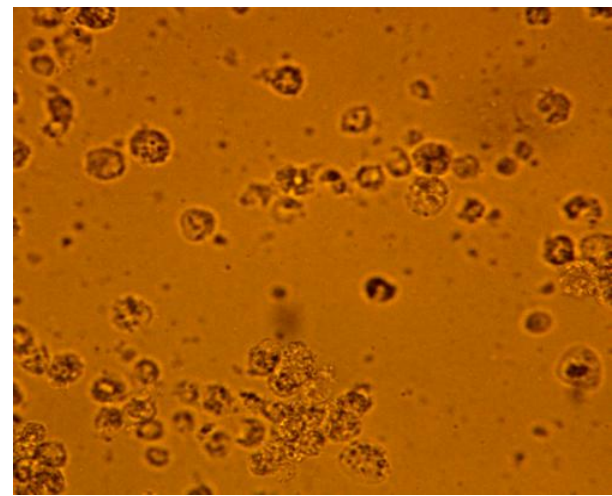

MCF-7 after treatment with L-Asparaginase Enzyme

Fig.4 Effect of L-asparaginase on the morphology of MDA-MB435S cell

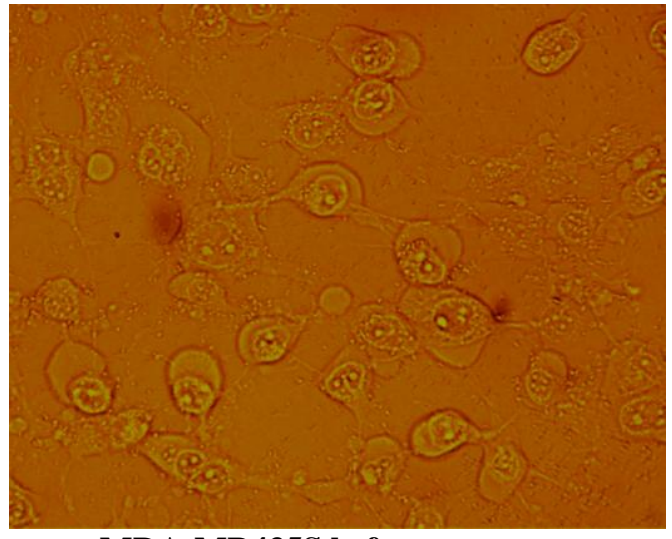

MDA-MB435S before treatment with L-Asparaginase enzyme

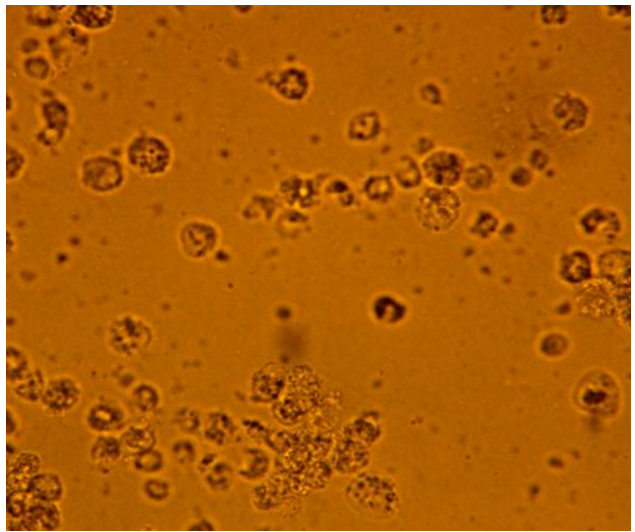

MDA-MB435S after treatment with L-Asparaginase enzyme

Fig.5 The effect of the combination of L-Asparaginase with cytostatic methotrexate on protein synthesis of MCF-7

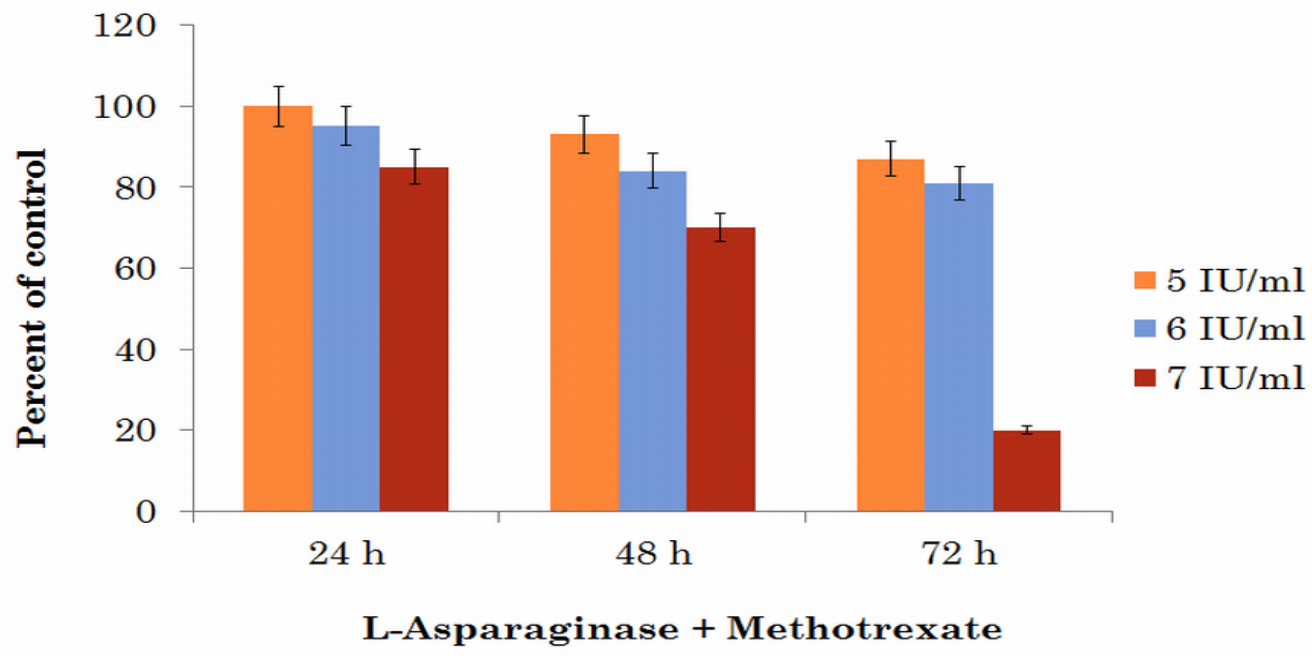


Fig.6 The effect of the combination of L-asparaginase with cytostatic methotrexate on cell growth of MCF-7

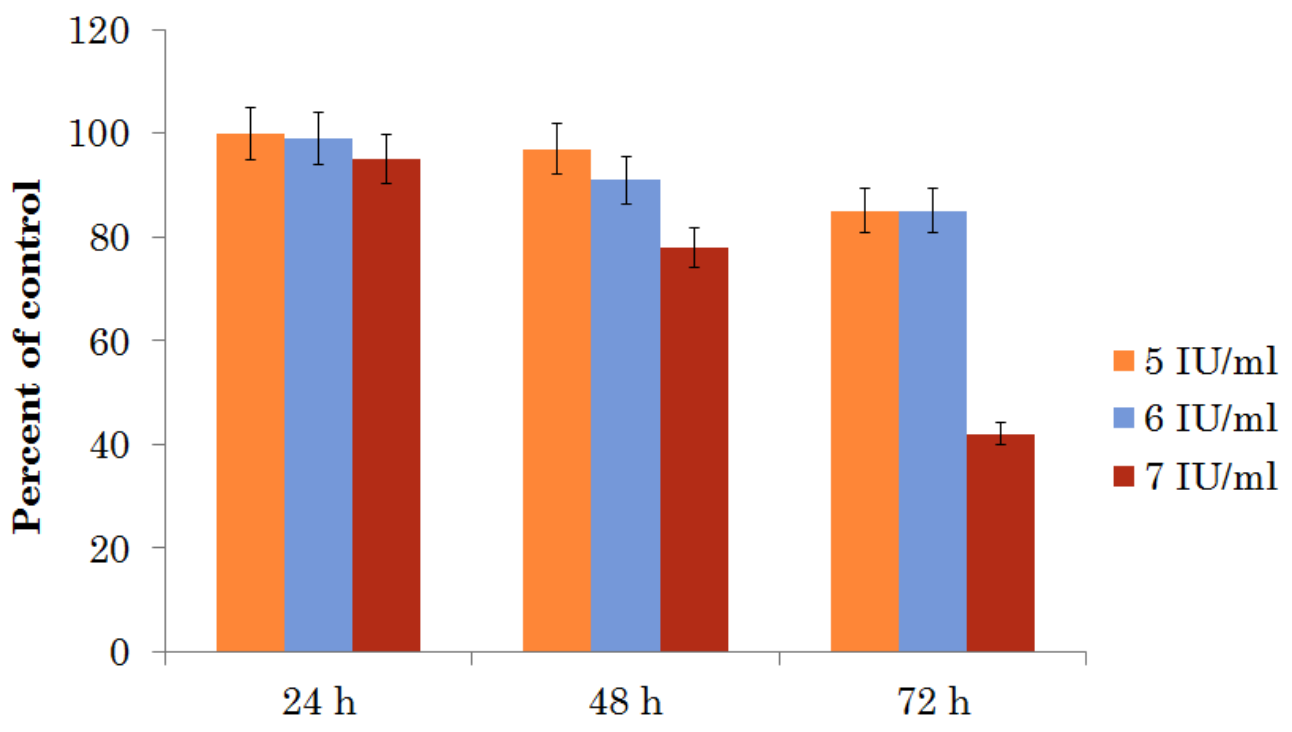

\section{L-Asparaginase + Methotrexate}

Fig.7 The effect of the combination of L-asparaginase with cytostatic methotrexate on protein synthesis of MDA-MB4352

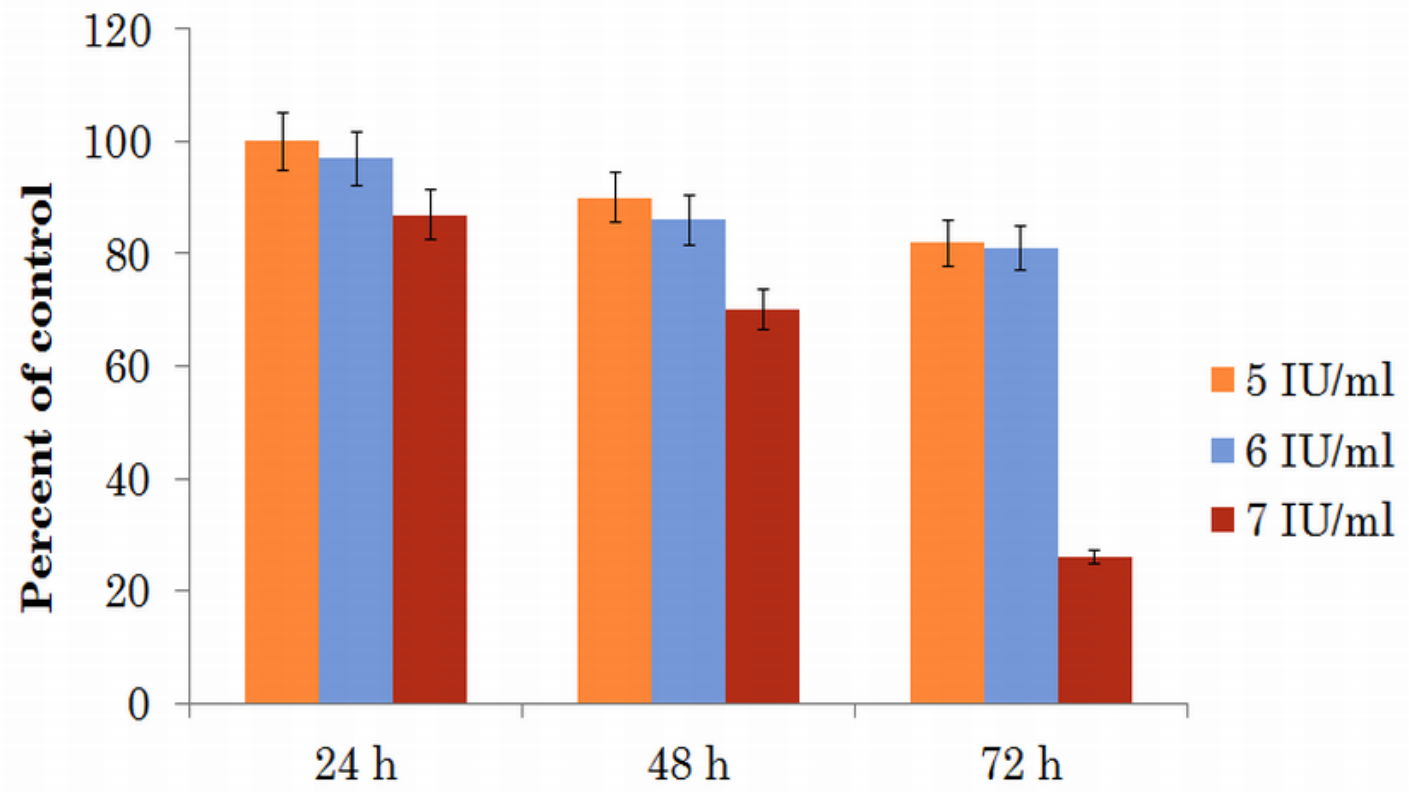

\section{L-Asparaginase + Methotrexate}

These results suggest that the isolated L-Asparaginase suppressed cell growth of both the tumor cell lines at certain doses starting from $6.25 \mu \mathrm{g} / \mathrm{ml}$. Our results on the antitumor cytotoxic toxicity of $S$. enissocaesilis Lasparaginase in vitro are rather optimistic. Asselin et al.,
(1989) demonstrated linear correlation between death of leukemia cells treated with asparaginases in vitro and in vivo. Thus, results of in vitro tests on asparaginase cytotoxic activity may be used for prediction of the enzyme activity or in vivo sensitivity to chemotherapy of 
acute lymphoblast leukemia and possibly solid tumors in humans.

\section{Flowcytometry}

It was demonstrated that treatments of MCF-7 and MDA-MB435S cell lines with $S$. enissocaesilis $L$ asparaginase had profound effect on the morphology of the cells (Figures 3 AND 4). At the same time cell cycle analysis by flow cytofluorimetry of MCF-7 and MDAMB435S cells treated with asparaginase and determination of the number of leukemic cells 24, 48, and $72 \mathrm{~h}$ after onset of asparaginase treatment suggest that under asparagine deficit these cells stop normal division (compared with corresponding control) and die. The number of these cells decreased within the time interval of this experiment (24-72 h). This is consistent with observation by Asselin et al., (1989).

Table 3 shows that treatment with L-asparaginases was effective in increasing the number of MCF-7 and MDAMB435S apoptotic cells. MCF-7 and MDA-MB435S cells containing almost $21.4 \%$ and $24.7 .7 \%$ of apoptotic cells in control demonstrated sensitivity: the number of apoptotic cells significantly increased after Lasparaginase treatment. The increase in the number of apoptotic cells up to $90 \%$ and $87 \%$ was observed in MCF-7 and MDA-MB435S cell lines, respectively after their combined treatment with L-asparaginase and methotrexate $(5 \mu \mathrm{g} / \mathrm{mL})$.

\section{Effect of L-asparaginase on cell growth and protien synthesis}

Experiments have been conducted to investigate whether administration of L-asparaginase, which results in hydrolysis of extracellular asparagine, arrests asparagine dependent protein synthesis and causes subsequent inhibition of cell growth followed by decreased proliferation of leukemic cells.

Figure $5 \& 6$ show the effect of combined treatment of L-asparaginase and cytostatic methotrexate $(5 \mu \mathrm{g} / \mathrm{mL})$ on the protein synthesis by MCF-7 and Figures 7 and 8 show the effect of combined treatment of L-asparaginase and cytostatic methotrexate $(5 \mu \mathrm{g} / \mathrm{mL})$ on MDAMB435S cells. Treatment of MCF-7 cells with Lasparaginase and methotrexate for 24-48 h insignificantly decreased protein synthesis, while the protein synthesis significantly decreased $(20 \%$ of control) after $72 \mathrm{~h}$ only at L-asparaginase of $7 \mathrm{IU} / \mathrm{mL}$; at asparaginase concentrations 2 and $5 \mathrm{IU} / \mathrm{mL}$ it remained elevated. The level of secretion demonstrated dependence to the asparaginase concentrations. Cell growth slightly differed from control cell growth at 24 and $48 \mathrm{~h}$. Treatment of cells for $72 \mathrm{~h}$ was accompanied by a sharp decrease of cell growth (42\% of control).

Protein synthesis in MDA-MB435S cells treated with of L-asparaginase and cytostatic methotrexate did not decrease below control values 24 and $48 \mathrm{~h}$ after asparaginase addition, but decreased at $72 \mathrm{~h}$ at asparaginase concentration of $7 \mathrm{IU} / \mathrm{mL}$ ( $26 \%$ of control). The combined treatment for $72 \mathrm{~h}$ the cell growth represented $50 \%$ of control.

In conclusion, this study implies that $S$. enissocaesilis Lasparaginase may be a potent drug for treatment of MCF7 and MDA-MB435S leukemia. The Cell cycle analysis by flow cytofluorimetry demonstrated that the Lasparaginase had profound effect on the morphology of the MCF-7 and MDA-MB435S cells and resulted in increased number of apoptotic cells. A linear correlation was observed between the number of the tumor cells and the dose- and time-dependent antitumor and cytotoxic effects of L-asparaginase from Streptomyces enissocaesilis. The administration of L-asparaginase resulted in hydrolysis of extracellular asparagines along with arrested asparagine dependent protein synthesis and caused subsequent inhibition of cell growth followed by decreased proliferation of leukemic cells. From the results, it is concluded that this L-asparaginase can be used for the development of new preparations for the therapy of tumors.

\section{References}

Asselin, B.L., Ryan, D., Frantz, Ch.N., Bernal, S.D., Leavitt, P., Sallan, S.E. and Cohen, H.J. 1989. In vitro and in vivo killing of acute lymphoblastic leukemia cells by L-asparaginase. Cancer Res., 49:4363-4368.

Fu, C., Nandy, P., Danenberg, P. and Avramis, V.I. 1998. Asparaginase (ASNase) induced cytotoxicity depends on the p53 status of the cells. Proceedings of the American Association for Cancer Research., 39:614-618.

Hashimoto, K., Suzuki, F. and Sakagami, H. 2009. Declined asparagine synthetase mRNA expression and enhanced sensitivity to asparaginase in HL-60 cells committed to monocytic differentiation. Anticancer Res., 29:1303-1308.

Nandy, P., Fu, C., Danenberg, P. and Avramis, V.I. 1998. Apoptosis induced by antimetabolites, taxanes 
or asparaginases in vitro depends on the p53 status of the leukaemic cells. Proceedings of the American Association for Cancer Research., 39:602-608.

Narta, U.K., Kanwar, S.S. and Azmi, W. 2007. Pharmacological and clinical evaluation of Laspaprginase in the treatment of leukemia. Crit Rev Oncol Hematol., 61:208-221.

Pasut, G., Sergi, M. and Veronese, F.M. 2007. Anticancer PEG-enzymes: 30 years old, but still a current approach. Advanced Drug Delivary Reviews.

Patro, K.R. and Gupta, N. 2012. Extraction, purification and characterization of $\mathrm{L}$ asparaginase from Penicillium sp. by submerged fermentation. International journal for Biotechnology and Molecular Biology research., 3(3):30-34.

Selvam, K. and Vishnupriya, B. 2013. Partial purification and cytotoxic activity of L-asparaginase from Streptomyces acrimycini NGP. International
Journal of Research in Pharmaceutical and Biomedical Sciences, 4(3):859-869.

Shimizu, T., Kubota, M., Adachi, S., Sano, H., Kasai, Y., Hashimoto, H., Akiyama. Y. and Mikawa H. 1992. Pre-treatment of a human T-lymphoblastoid cell line with 1-asparaginase reduces etoposide induced DNA strand breakage and cytotoxicity. International Journal of Cancer, 50:644-648.

Uyttebroeck, A., Suciu, S., Laureys, G., Robert, A. and Pacquement Ferster, A. 2008. Treatment of childhood T-cell lymphoblastic lymphoma according to the strategy for acute lymphoblastic leukaemia, without radiotherapy: long term results of the EORTC CLG 58881 trial. European Journal of Cancer, 44:840-846.

Walker, P.R., Kwast_Welfeld, J., Gourdeau, H., Leblanc, J., Neugebauer, W. and Sikorska, M. 1993. Exp. Cell Res., 207:1420-1451.

\section{How to cite this article:}

Sirisha, B., and Haritha, R. 2017. Efficacy of the Antiproliferative Effect of L-Asparaginase from Streptomyces enissocaesilis on Different Tumor Cell Lines. Int.J.Curr.Res.Aca.Rev. 5(7), 95-102.

doi: https://doi.org/10.20546/ijcrar.2017.507.013 